BMJ Open

Diabetes

Research

\& Care

\title{
Lixisenatide is effective and safe as add- on treatment to basal insulin in Asian individuals with type 2 diabetes and different body mass indices: a pooled analysis of data from the GetGoal Studies
}

\author{
Wenhuan Feng, ${ }^{1}$ Weimin Wang, ${ }^{1}$ Ran Meng, ${ }^{1}$ Guangyu $\mathrm{Wu},{ }^{2}$ Minlu Zhang, ${ }^{2}$ \\ Xia Zhang, ${ }^{2}$ Huiqiu Yin, ${ }^{2}$ Dalong Zhu (D) ${ }^{1}$
}

To cite: Feng W, Wang W, Meng R, et al. Lixisenatide is effective and safe as add-on treatment to basal insulin in Asian individuals with type 2 diabetes and different body mass indices: a pooled analysis of data from the GetGoal Studies. BMJ Open Diab Res Care 2021;9:e002290. doi:10.1136/ bmjdrc-2021-002290

- Additional supplemental material is published online only. To view, please visit the journal online (http://dx.doi. org/10.1136/bmjdrc-2021002290).

WF and WW contributed equally.

Received 23 March 2021 Accepted 17 July 2021

Check for updates

(c) Author(s) (or their employer(s)) 2021. Re-use permitted under CC BY-NC. No commercial re-use. See rights and permissions. Published by BMJ.

For numbered affiliations see end of article.

Correspondence to Dr Dalong Zhu; zhudalong@nju.edu.cn

\section{ABSTRACT}

Introduction This analysis aims to investigate the efficacy and safety of once-daily lixisenatide add-on treatment to basal insulin in Asian individuals with type 2 diabetes, by baseline body mass index (BMI).

Research design and methods Data from all Asian participants in the placebo-controlled GetGoal-Duo 1, GetGoal-L, and GetGoal-L-C Studies were pooled and categorized according to the following BMI subgroups: $<25 \mathrm{~kg} / \mathrm{m}^{2}, 25-<30 \mathrm{~kg} / \mathrm{m}^{2}$ and $\geq 30 \mathrm{~kg} / \mathrm{m}^{2}$. Efficacy and safety of lixisenatide versus placebo were evaluated among BMI subgroups. Multivariable regression analyses were also conducted to explore the potential influence of BMI on efficacy outcomes after adjusting for baseline characteristics.

Results 555 participants were included (mean age 53.9 years, $52.4 \%$ men). No significant differences in treatment effect between the BMl subgroups were observed for the changes from baseline to 24 weeks in glycated hemoglobin $(\mathrm{HbA} 1 \mathrm{c})$, fasting plasma glucose, postprandial glucose (PPG), PPG excursion, body weight, BMI, and basal insulin dose with lixisenatide, as well as the change in basal insulin dose at study endpoint and the proportion of participants achieving an $\mathrm{HbA} 1 \mathrm{c}<7 \%$ at 24 weeks (all $p$ values for interaction $>0.15$ ). In the multivariable regression analysis, participants in the lowest BMI group had a smaller reduction in body weight over the 24week treatment period relative to the highest BMI group $(p=0.023)$.

Conclusions This post hoc analysis indicates that lixisenatide improved glycemic control regardless of baseline BMI and was well tolerated in Asian individuals unable to achieve their $\mathrm{HbA1c}$ target on basal insulin \pm oral antidiabetic drugs.

\section{INTRODUCTION}

Type 2 diabetes (T2D) is a metabolic disease resulting from insulin resistance and $\beta$-cell dysfunction, both of which worsen over time making treatment intensification a

\section{Significance of this study}

What is already known about this subject?

- Data from the GetGoal clinical study program demonstrate that, compared with add-on placebo, add-on lixisenatide was consistently associated with significantly greater reductions in glycated hemoglobin ( $\mathrm{HbA1c}$ ) and postprandial glucose (PPG), in individuals with type 2 diabetes also receiving basal insulin \pm oral antidiabetic drugs (OADs), irrespective of the concomitant OAD regimen.

- Because of their effect on weight loss and diabetes, most clinical research with glucagon-like peptide-1 agonists has been conducted in obese/overweight individuals, but the impact of body mass index (BMI) on the effect of lixisenatide +basal insulin in Asian individuals is unknown.

What are the new findings?

- No significant differences in the beneficial effect of lixisenatide in Asian participants also receiving basal insulin \pm OADs were observed when data were analyzed by baseline BMI.

- Changes from baseline to 24 weeks in $\mathrm{HbA1c}$, fasting plasma glucose, PPG, PPG excursion, body weight, BMI, and basal insulin dose, and the proportion of participants achieving an $\mathrm{HbA} 1 \mathrm{C}<7 \%$ at 24 weeks, with lixisenatide were similar between participants with a baseline $\mathrm{BMl}<25 \mathrm{~kg} / \mathrm{m}^{2}, 25-<30 \mathrm{~kg} / \mathrm{m}^{2}$ and $\geq 30 \mathrm{~kg} / \mathrm{m}^{2}$.

How might these results change the focus of research or clinical practice?

- Add-on lixisenatide can be used to optimize glycemic control in Asian individuals with type 2 diabetes unable to achieve their $\mathrm{HbA1c}$ glycemic targets on basal insulin \pm OADs, irrespective of the individual's BMI.

therapeutic necessity in almost every individual. ${ }^{12}$ Over the past four decades, the worldwide prevalence of T2D has increased 
considerably, particularly in developing countries such as China and countries in South-East Asia. ${ }^{3}$ This increase in the prevalence of T2D in Asia has been in parallel with a rise in obesity, ${ }^{4}$ a known risk factor for T2D ${ }^{5}$ which is thought to be due to the adoption of sedentary lifestyles and energy-dense Western diets. ${ }^{6-8}$ Furthermore, it is typically harder to control blood glucose levels in individuals with T2D who are obese versus those who are not. ${ }^{9}$

There are some differences in the pathogenesis of T2D between Asian and non-Asian individuals. ${ }^{10}$ Historically, studies have shown that, compared with non-Asian individuals, T2D in Asian individuals was characterized more by reduced $\beta$-cell function than by insulin resistance. ${ }^{11-13}$ However, with the increase in obesity seen in Asia over the last four decades, the influence of insulin resistance in Asian individuals with T2D is rising. ${ }^{14-18}$ While the prevalence of obesity in China and other Asian countries is still lower than in the USA and Europe, ${ }^{19}$ at any given body mass index (BMI), an Asian person will have more visceral fat, which can be associated with a heightened risk of dysglycemia, ${ }^{20}$ than a non-Asian person of the same age and sex. ${ }^{10}$ Due to all of these differences, the pathophysiology of T2D in Asian individuals with T2D is now characterized by both more impaired $\beta$-cell function and worse insulin resistance than in non-Asian individuals, ${ }^{15-18}$ meaning that more intensive and customized treatment strategies for Asian individuals with T2D are needed.

A high proportion of individuals with T2D require additional treatment within 1-2 years of starting treatment with basal insulin to reach or maintain glycemic targets. $^{21}{ }^{22}$ When add-on therapy is required for individuals on basal insulin, one recommended option is glucagon-like peptide-1 (GLP-1) receptor agonists. ${ }^{23}$ Basal insulin and GLP-1 receptor agonists have complementary mechanisms of action, making the two agents a rational therapeutic combination. ${ }^{24}$ While a key mechanism of the GLP-1 receptor agonists is to stimulate insulin secretion from $\beta$-cells, the short-acting agents, such as lixisenatide, also slow gastric emptying and suppress appetite and glucagon secretion, which leads to marked reductions in postprandial glucose (PPG) ${ }^{2526}$ In contrast, basal insulin lowers fasting plasma glucose $(\mathrm{FPG}) .^{2}{ }^{24}$ Studies have shown that adding a GLP-1 receptor agonist is more effective at reducing glycated hemoglobin (HbA1c) levels than increasing the dose of basal insulin, and is associated with a lower incidence of hypoglycemia than adding a rapid-acting insulin or increasing the basal insulin dose. ${ }^{27}$ An indirect network meta-analysis of data with different antidiabetic treatments as add-on therapy to basal insulin found that GLP-1 receptor agonists were associated with the greatest HbAlc-lowering effects, and were one of two drug classes (along with sodium-glucose cotransporter-2 inhibitors) associated with the greatest body weight reduction. ${ }^{28}$

The GetGoal clinical study program evaluated the efficacy and safety of lixisenatide as add-on therapy to basal insulin \pm oral antidiabetic drugs (OADs) in individuals with T2D and found that, compared with placebo +basal insulin, lixisenatide +basal insulin was consistently associated with a significantly greater reduction in $\mathrm{HbAlc}$ and PPG, irrespective of the concomitant OAD regimen. ${ }^{29-32} \mathrm{~A}$ pooled analysis of data from three similar GetGoal Studies (GetGoal-Duo 1, GetGoal-L and GetGoal-L-C) demonstrated that mean changes in HbA1c with lixisenatide + basal insulin were similar in participants across a range of BMIs. ${ }^{33}$ However, given the differences between Asian and non-Asian individuals with T2D and the substantial rise in obesity in Asian countries in the last four decades, it is also important to establish that the efficacy and safety of lixisenatide and basal insulin are consistent across BMI subgroups in Asian people, particularly since lixisenatide is the only GLP-1 receptor antagonist currently approved in China for use with basal insulin. Since the GetGoal Studies included some Asian patients, participants in these studies provided an opportunity to examine the effect of BMI on outcomes with lixisenatide and basal insulin specifically in Asian individuals with T2D. As such, the aim of this post hoc analysis was to investigate the efficacy and safety of lixisenatide and basal insulin according to baseline BMI, using pooled data from the Asian cohorts of participants in GetGoal Duo $1,^{30}$ GetGoal-L, ${ }^{29}$ and GetGoal-L-C. ${ }^{32}$

\section{RESEARCH DESIGN AND METHODS}

\section{Study designs and participants}

This post hoc analysis examined efficacy and safety data obtained from all Asian participants in the intent-totreat populations of the GetGoal-Duo 1 (ClinicalTrials. gov record: NCT00975286), GetGoal-L (ClinicalTrials. gov record: NCT00715624) and GetGoal-L-C (ClinicalTrials.gov record: NCT01632163) Studies. Full details of the study designs and results for the overall populations have been published previously. ${ }^{29}{ }^{30}$ Briefly, participants in these randomized, double-blind, placebo-controlled studies had T2D with an HbA1c $\geq 7 \%$ despite basal insulin and other therapies. In GetGoal-Duo 1, lixisenatide or placebo was added to treatment with insulin glargine and metformin $\pm \mathrm{a}$ sulfonylurea, glinide or thiazolidinedione ${ }^{30}$ whereas in GetGoal-L, participants were receiving lixisenatide or placebo treatment in combination with insulin glargine \pm metformin. ${ }^{29}$ GetGoal-L-C had the same design as GetGoal-L, but in a predominantly Asian population. ${ }^{32}$

In all three studies, lixisenatide was administered as a once-daily injection starting at a dose of $10 \mu \mathrm{g}$. In GetGoal-L and GetGoal-Duo 1, the lixisenatide dose was increased at 1-week intervals, first to $15 \mu \mathrm{g}$ and then to $20 \mu \mathrm{g}$ if tolerated. ${ }^{29}{ }^{30}$ In GetGoal-L-C, the lixisenatide dose was increased to $20 \mu \mathrm{g}$ after 2 weeks on the starting dose. $^{32}$ All participants provided written informed consent. 


\section{Efficacy and safety outcomes}

The primary endpoint in all three studies was the change in $\mathrm{HbA1c}$ from baseline at 24 weeks after randomization. ${ }^{29} 3032$ Secondary endpoints included changes from baseline to week 24 in FPG, 2-hour PPG, PPG excursion, body weight, BMI and basal insulin dose. The proportion of individuals achieving an $\mathrm{HbAlc}<7 \%$, as well as the proportion of individuals achieving a variety of combined endpoints with $\mathrm{HbA} 1 \mathrm{c}<7 \%$, and no symptomatic hypoglycemia, severe hypoglycemia or gain in body weight, were also assessed.

Safety endpoints included the incidence and frequency of hypoglycemia (severe hypoglycemia, any symptomatic hypoglycemia, and symptomatic hypoglycemia with a blood glucose $<3.3 \mathrm{mmol} / \mathrm{L}$ ), as well as the frequency of gastrointestinal adverse events (nausea, vomiting, and diarrhea).

\section{Statistical analysis}

Despite above-mentioned pathophysiology differences in Asian and non-Asian people with T2D, available clinical data do not necessarily indicate a clear BMI cut-off point for all Asians, and as such, the WHO recommends using their internationally recommended BMI classifications in clinical practice. In this analysis, participantlevel data were pooled and categorized according to the following BMI subgroups: $<25 \mathrm{~kg} / \mathrm{m}^{2}, 25-<30 \mathrm{~kg} / \mathrm{m}^{2}$ and $\geq 30 \mathrm{~kg} / \mathrm{m}^{2}$. These are the internationally used BMI cut-offs, used to define 'normal weight', 'overweight' and 'obese', respectively, which are recommended by the WHO for use in all populations, including those of Asian descent. ${ }^{34}$ Descriptive statistics, including mean and SD for continuous variables and number and proportion for categorical variables, were used to summarize participant demographics, clinical characteristics, and efficacy and safety outcomes. Differences between BMI subgroups were tested using a $\chi 2$ test for categorical variables and t-tests, one-way analysis of variance or Kruskal-Wallis tests for continuous variables. Differences between lixisenatide and placebo within each BMI subgroup were examined using analysis of covariance models for change from baseline to week 24 in HbA1c, FPG, 2-hour PPG, 2-hour PPG excursion, body weight, BMI and basal insulin dose; least squares mean (LSM) and SE for each treatment group and LSM difference (SE, 95\% CIs, and p values) between treatment groups were reported. Logistic regression was used to test treatment difference in each BMI subgroup for $\mathrm{HbA1c}<7 \%$ at week 24, and OR, 95\% CIs and $\mathrm{p}$ values were calculated. The model included a multiplicative interaction term of BMI subgroup $\times$ treatment group to assess potential inconsistency in the treatment effect of lixisenatide across BMI subgroups. Covariates in all of the regression analyses included randomization strata of HbAlc $(<8 \%, \geq 8 \%)$, study (GetGoal-L, GetGoal-L-C, GetGoal-Duo 1), age, gender, and baseline FPG, 2-hour PPG, HbAlc, BMI, basal insulin dose and duration of diabetes.
A two-sided $\mathrm{p}$ value of $\leq 0.05$ was considered to be statistically significant. Statistical analyses were performed using SAS V.9.3.

\section{RESULTS}

\section{Participant characteristics}

Of the 1389 participants of the GetGoal-L, GetGoalL-C and GetGoal-Duo 1 Studies, 555 were Asian and included in this analysis (mean age 53.9 years, $52.4 \%$ men). Of these, $183(33.0 \%)$ had a BMI $<25 \mathrm{~kg} / \mathrm{m}^{2}$ at baseline, $276(49.7 \%)$ had a BMI of $25-<30 \mathrm{~kg} / \mathrm{m}^{2}$ and $96(17.3 \%)$ had a BMI of $\geq 30 \mathrm{~kg} / \mathrm{m}^{2}$. Significant differences in body weight $(\mathrm{p}<0.001)$, basal daily insulin dose (units/day; $p<0.001)$, duration of diabetes $(p=0.044)$, gender $(p=0.028)$ and age $(p=0.001)$ were observed between the BMI subgroups (table 1 ).

Compared with participants of other Asian ethnicities included in this analysis, Chinese participants had significantly higher baseline FPG and PPG levels and body weight, a shorter duration of basal insulin treatment, were receiving a significantly lower basal insulin dose, and had a lower BMI (online supplemental table 1).

\section{Efficacy}

No significant differences were found for treatment effect between the BMI subgroups in the changes from baseline in $\mathrm{HbA1c}, \mathrm{FPG}$, 2-hour PPG, 2-hour PPG excursion, body weight, BMI, and basal insulin dose to week 24 (all p values for interaction $>0.15$; table 2 , online supplemental table 2).

After 24 weeks of treatment, lixisenatide significantly reduced HbA1c (LSM difference $-0.51 \%$; 95\% CI $-0.68 \%$ to $-0.33 \%$; $<<0.001)$, 2-hour PPG (LSM difference $-3.52 \mathrm{mmol} / \mathrm{L} ; 95 \% \mathrm{CI}-4.31$ to $-2.73 ; \mathrm{p}<0.001)$ and 2-hour PPG excursion (LSM difference $-3.09 \mathrm{mmol} / \mathrm{L}$; 95\% CI -3.81 to $-2.38 ; \mathrm{p}<0.001)$ levels from baseline compared with placebo in the overall cohort (all BMI subgroups combined; table 2). Body weight and BMI were also significantly reduced from baseline with lixisenatide compared with placebo in participants in the lower BMI subgroups $\left(<25 \mathrm{~kg} / \mathrm{m}^{2}:\right.$ LSM difference $-0.92 \mathrm{~kg} ; 95 \%$ CI -1.44 to $-0.39 ; \mathrm{p}<0.001$ and $-0.34 \mathrm{~kg} /$ $\mathrm{m}^{2} ; 95 \%$ CI -0.54 to $-0.15 ; \mathrm{p}<0.001 ; 25-<30 \mathrm{~kg} / \mathrm{m}^{2}: \mathrm{LSM}$ difference $-1.14 \mathrm{~kg} ; 95 \% \mathrm{CI}-1.71$ to $-0.56 ; \mathrm{p}<0.001$ and $-0.41 \mathrm{~kg} / \mathrm{m}^{2} ; 95 \%$ CI -0.63 to $\left.-0.20 ; \mathrm{p}<0.001\right)$, but not significantly reduced in the higher BMI subgroup $\left(\geq 30 \mathrm{~kg} / \mathrm{m}^{2}:\right.$ LSM difference $-0.96 \mathrm{~kg} ; 95 \%$ CI -2.12 to $0.19 ; \mathrm{p}=0.100$ and $-0.37 \mathrm{~kg} / \mathrm{m}^{2} ; 95 \% \mathrm{CI}-0.81$ to 0.07 ; $\mathrm{p}=0.101$, respectively).

FPG was significantly reduced from baseline with lixisenatide compared with placebo in participants in the higher BMI subgroup ( $\geq 30 \mathrm{~kg} / \mathrm{m}^{2}$ : LSM difference $-1.21 \mathrm{mmol} / \mathrm{L} ; 95 \% \mathrm{CI}-2.21$ to $-0.21 ; \mathrm{p}=0.019)$, but not in the lower BMI subgroups $\left(<25 \mathrm{~kg} / \mathrm{m}^{2}\right.$ : LSM difference $-0.39 \mathrm{mmol} / \mathrm{L} ; 95 \%$ CI -1.03 to $0.25 ; \mathrm{p}=0.234$; $25-<30 \mathrm{~kg} / \mathrm{m}^{2}:$ LSM difference $-0.10 \mathrm{mmol} / \mathrm{L} ; 95 \% \mathrm{CI}$ 
Table 1 Baseline characteristics by baseline body mass index (BMI) subgroup

\begin{tabular}{|c|c|c|c|c|c|c|c|c|c|c|}
\hline \multirow[b]{2}{*}{ Characteristic } & \multicolumn{3}{|c|}{ BMI $<25 \mathrm{~kg} / \mathrm{m}^{2}$} & \multicolumn{3}{|c|}{ BMI $25-<30 \mathrm{~kg} / \mathrm{m}^{2}$} & \multicolumn{3}{|c|}{$\mathrm{BMI} \geq 30 \mathrm{~kg} / \mathrm{m}^{2}$} & \multirow[b]{2}{*}{ P value ${ }^{\star}$} \\
\hline & $\begin{array}{l}\text { PBO } \\
(n=79)\end{array}$ & $\begin{array}{l}\text { ㄴIXXI } \\
(n=104)\end{array}$ & $\begin{array}{l}\text { Total } \\
(n=183)\end{array}$ & $\begin{array}{l}\text { PBO } \\
(n=142)\end{array}$ & $\begin{array}{l}\text { 니XI } \\
(n=134)\end{array}$ & $\begin{array}{l}\text { Total } \\
(n=276)\end{array}$ & $\begin{array}{l}\text { PBO } \\
(n=42)\end{array}$ & $\begin{array}{l}\text { LIXI } \\
(n=54)\end{array}$ & $\begin{array}{l}\text { Total } \\
(n=96)\end{array}$ & \\
\hline Age, years & $56.0 \pm 9.9$ & $54.3 \pm 9.9$ & $55.0 \pm 9.9$ & $55.1 \pm 9.1$ & $53.4 \pm 9.4$ & $54.3 \pm 9.3$ & $50.2 \pm 7.7$ & $51.2 \pm 10.5$ & $50.8 \pm 9.4$ & 0.001 \\
\hline Male, n (\%) & $40(50.6)$ & $51(49.0)$ & $91(49.7)$ & 76 (53.5) & $83(61.9)$ & 159 (57.6) & $23(54.8)$ & 18 (33.3) & $41(42.7)$ & 0.028 \\
\hline $\mathrm{HbA} 1 \mathrm{c}, \%$ & $7.9 \pm 0.7$ & $8.0 \pm 0.7$ & $8.0 \pm 0.7$ & $8.0 \pm 0.7$ & $8.0 \pm 0.8$ & $8.0 \pm 0.8$ & $8.1 \pm 0.8$ & $8.0 \pm 0.8$ & $8.1 \pm 0.8$ & 0.559 \\
\hline $\begin{array}{l}\text { Duration of } \\
\text { diabetes, years }\end{array}$ & $10.6 \pm 6.1$ & $11.2 \pm 6.6$ & $11.0 \pm 6.4$ & $10.4 \pm 6.3$ & $10.0 \pm 6.0$ & $10.2 \pm 6.1$ & $8.6 \pm 6.6$ & $9.2 \pm 6.5$ & $9.0 \pm 6.6$ & 0.044 \\
\hline $\begin{array}{l}\text { Duration of } \\
\text { basal insulin, } \\
\text { yearst }\end{array}$ & $2.3 \pm 2.4$ & $2.5 \pm 3.0$ & $2.4 \pm 2.8$ & $2.5 \pm 2.7$ & $2.0 \pm 2.4$ & $2.3 \pm 2.5$ & $1.7 \pm 1.7$ & $2.3 \pm 2.6$ & $2.1 \pm 2.2$ & 0.577 \\
\hline $\mathrm{FPG}, \mathrm{mmol} / \mathrm{L}$ & $6.8 \pm 1.8$ & $7.1 \pm 2.3$ & $7.0 \pm 2.1$ & $6.7 \pm 1.8$ & $7.1 \pm 2.2$ & $6.9 \pm 2.0$ & $7.1 \pm 2.1$ & $6.9 \pm 1.7$ & $7.0 \pm 1.9$ & 0.921 \\
\hline $\begin{array}{l}\text { 2-hour PPG, } \\
\mathrm{mmol} / \mathrm{L}\end{array}$ & $14.1 \pm 3.4$ & $14.7 \pm 4.9$ & $14.4 \pm 4.3$ & $14.2 \pm 3.9$ & $13.9 \pm 4.2$ & $14.1 \pm 4.0$ & $14.1 \pm 3.8$ & $12.9 \pm 3.8$ & $13.4 \pm 3.8$ & 0.143 \\
\hline $\begin{array}{l}\text { Basal insulin } \\
\text { dose, U/day }\end{array}$ & $30.7 \pm 11.6$ & $33.3 \pm 13.5$ & $32.2 \pm 12.7$ & $38.1 \pm 15.1$ & $37.4 \pm 16.2$ & $37.8 \pm 15.6$ & $52.2 \pm 31.4$ & $50.1 \pm 22.4$ & $51.0 \pm 26.6$ & $<0.001$ \\
\hline $\begin{array}{l}\text { Basal insulin } \\
\text { dose, U/day/kg }\end{array}$ & $0.5 \pm 0.2$ & $0.6 \pm 0.2$ & $0.5 \pm 0.2$ & $0.5 \pm 0.2$ & $0.5 \pm 0.2$ & $0.5 \pm 0.2$ & $0.6 \pm 0.3$ & $0.6 \pm 0.3$ & $0.6 \pm 0.3$ & 0.154 \\
\hline BMI, kg/m² & $23.0 \pm 1.3$ & $23.2 \pm 1.3$ & $23.2 \pm 1.3$ & $27.4 \pm 1.5$ & $27.1 \pm 1.4$ & $27.2 \pm 1.5$ & $33.4 \pm 2.5$ & $32.9 \pm 2.5$ & $33.1 \pm 2.5$ & \\
\hline $\begin{array}{l}\text { Body weight, } \\
\text { kg }\end{array}$ & $61.9 \pm 7.4$ & $61.6 \pm 7.4$ & $61.7 \pm 7.4$ & $73.0 \pm 9.9$ & $73.5 \pm 9.7$ & $73.2 \pm 9.8$ & $89.4 \pm 10.5$ & $85.3 \pm 11.8$ & $87.1 \pm 11.4$ & \\
\hline
\end{tabular}

All values are given as mean \pm SD unless otherwise stated.

${ }^{*} P$ value for differences between total participants of the different BMI subgroups.

tOnly available for GetGoal-L and GetGoal-L-C Studies.

FPG, fasting plasma glucose; HbA1c, glycated hemoglobin; LIXI, lixisenatide; PBO, placebo; PPG, postprandial glucose.

-0.65 to $0.46 ; \mathrm{p}=0.731)$ or overall study population (LSM difference $-0.34 ; 95 \%$ CI -0.72 to $0.03 ; \mathrm{p}=0.074$; table 2).

The changes in basal insulin dose (units/day) from baseline to week 24 were significantly different between lixisenatide and placebo recipients in the lower BMI subgroups $\left(<25 \mathrm{~kg} / \mathrm{m}^{2}\right.$ and $\left.25-<30 \mathrm{~kg} / \mathrm{m}^{2}\right)$, but not the higher BMI subgroup $\left(\geq 30 \mathrm{~kg} / \mathrm{m}^{2}\right)$. When assessed by body weight, the changes in basal insulin dose (units/ $\mathrm{kg}$ /day) from baseline to week 24 were significantly different between lixisenatide and placebo recipients only in the lowest BMI subgroup $\left(<25 \mathrm{~kg} / \mathrm{m}^{2}\right.$; online supplemental table 2).

In all BMI subgroups, significantly more participants receiving lixisenatide than participants receiving placebo achieved an HbA1c $<7 \%$ at week 24 (table 2). The proportions of participants who achieved an HbAlc $<7 \%$ ranged between $33.1 \%$ and $34.0 \%$ with lixisenatide and between $9.5 \%$ and $15.0 \%$ with placebo across the BMI subgroups. The proportion of participants achieving an $\mathrm{HbA} 1 \mathrm{c}<7 \%$ did not significantly differ between BMI subgroups.

There was a significant difference between BMI subgroups in the proportions of participants who achieved an HbA1c $<7 \%$ with no symptomatic hypoglycemia with a blood glucose $<3.3 \mathrm{mmol} / \mathrm{L}$ and no body weight gain $(p=0.047$; figure 1$)$. In contrast, the proportions of participants who achieved the other evaluated composite endpoints did not significantly differ between BMI subgroups (figure 1). Furthermore, more participants receiving lixisenatide (online supplemental figure 1A) achieved the composite endpoints compared with participants receiving placebo (online supplemental figure 1B).

\section{Safety}

No participants in this pooled analysis experienced severe hypoglycemia (table 3). The proportion of participants with any symptomatic hypoglycemia or symptomatic hypoglycemia with a confirmed blood glucose $<3.3 \mathrm{mmol} / \mathrm{L}$ over the 24 -week treatment period was low and similar between the BMI subgroups, with no statistically significant difference observed between the BMI subgroups ( $\mathrm{p}=0.788$ and $\mathrm{p}=0.939$ for any symptomatic hypoglycemia and symptomatic hypoglycemia with a blood glucose $<3.3 \mathrm{mmol} / \mathrm{L}$, respectively).

The proportion of participants who experienced a gastrointestinal adverse event appeared to be similar between the BMI subgroups. Individuals receiving lixisenatide experienced more gastrointestinal adverse events, such as nausea, vomiting or diarrhea, compared with individuals who received placebo (table 3 ).

\section{Multivariable regression analysis}

After adjusting for baseline characteristics (treatment group, age, gender, FPG, 2-hour PPG, HbAlc, basal insulin dose/body weight and duration of diabetes), participants in the lowest BMI group $\left(<25 \mathrm{~kg} / \mathrm{m}^{2}\right)$ relative to the highest BMI group $\left(\geq 30 \mathrm{~kg} / \mathrm{m}^{2}\right)$ had a smaller reduction in body weight over the 24-week treatment period (estimated difference $0.68 \mathrm{~kg}$; $95 \%$ CI 0.09 to 1.26 ; $\mathrm{p}=0.023$; table 4). Participants in the lowest BMI groups $\left(<25 \mathrm{~kg} / \mathrm{m}^{2}\right.$ and $\left.25-<30 \mathrm{~kg} / \mathrm{m}^{2}\right)$ also had a lower basal insulin dose (units/day) at the end of the study relative to 


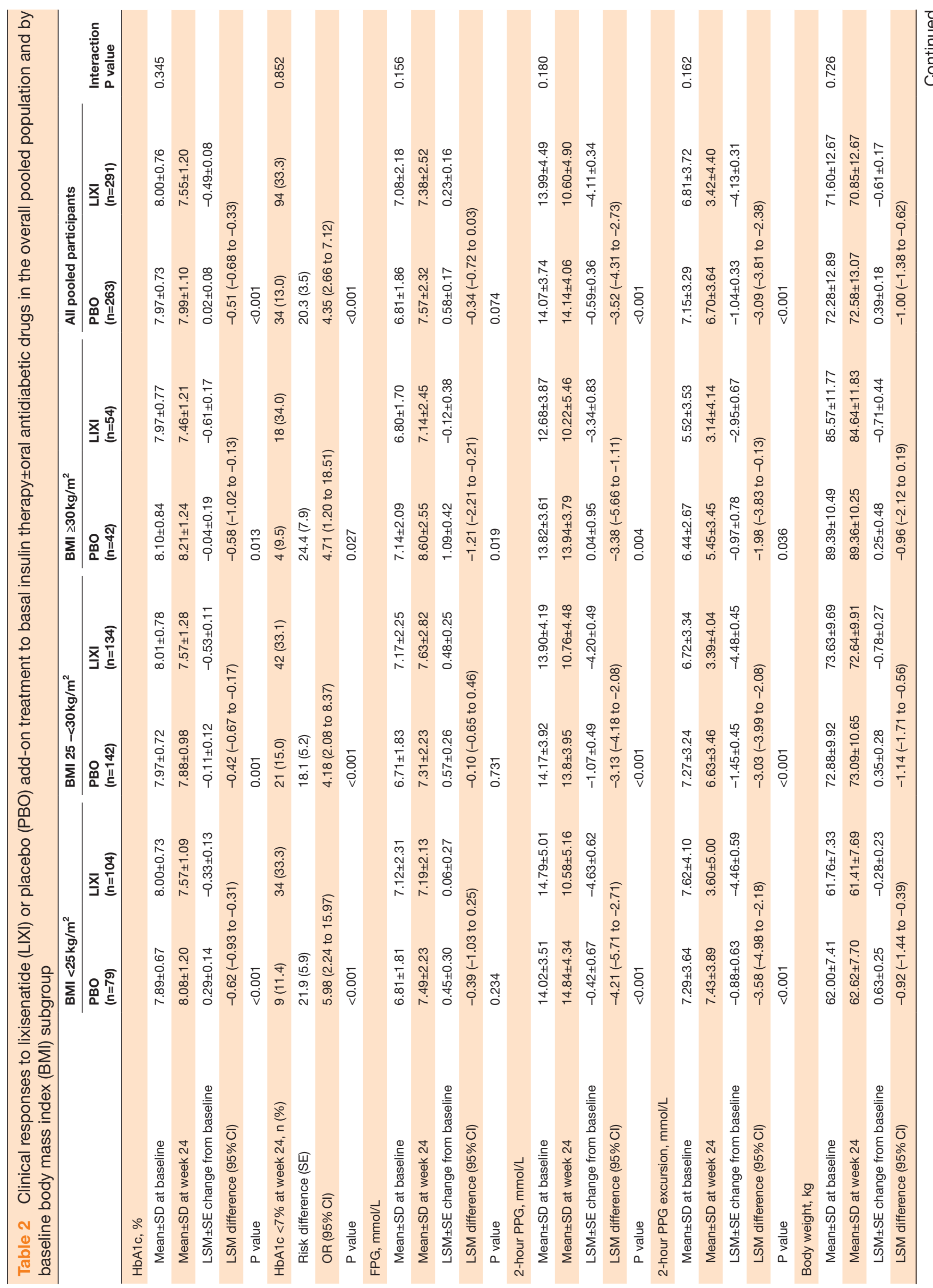




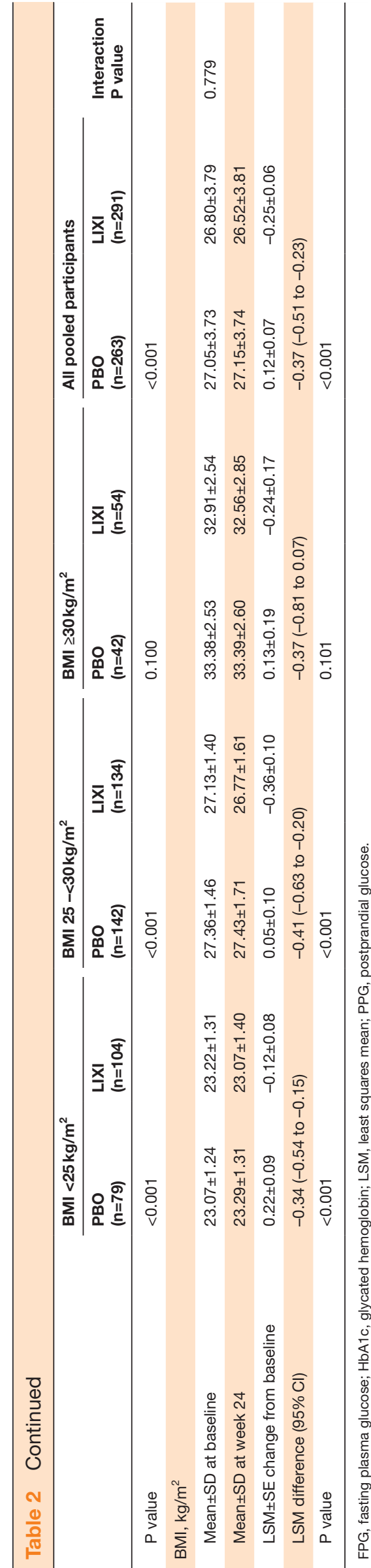

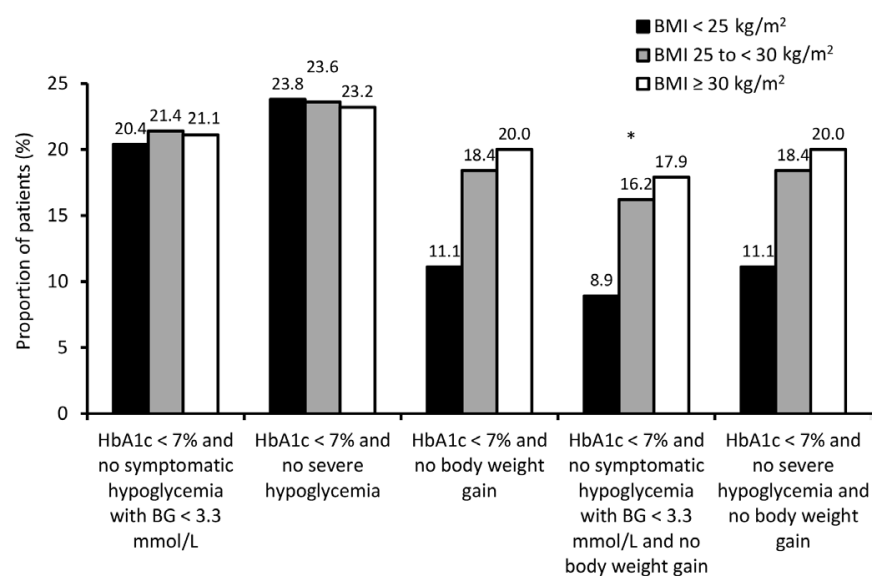

Figure 1 Proportion of all study participants achieving the composite endpoints by baseline body mass index (BMI) subgroup. ${ }^{*} \mathrm{P}=0.047$. $\mathrm{BG}$, blood glucose; HbA1c, glycated hemoglobin.

the highest BMI group ( $\geq 30 \mathrm{~kg} / \mathrm{m}^{2}$; estimated difference both $\mathrm{p}<0.001)$. However, there was no significant difference among the different BMI subgroups in the change in basal insulin dose from baseline to week 24. Changes in HbA1c, FPG, and 2-hour PPG from baseline to week 24 were not significantly different among the different BMI subgroups. Also, the likelihood of achieving an HbAlc $<7 \%$ was similar among the different BMI subgroups. Finally, participants in the lowest BMI subgroup $(<25 \mathrm{~kg} /$ $\mathrm{m}^{2}$ ) had a lower likelihood of achieving an HbAlc $<7 \%$ with no body weight gain (OR 0.40; $95 \%$ CI 0.18 to 0.90 ; $\mathrm{p}=0.005)$ relative to the highest BMI subgroup ( $\geq 30 \mathrm{~kg} /$ $\mathrm{m}^{2}$; table 4).

\section{DISCUSSION}

The results of this pooled post hoc analysis demonstrate that, regardless of baseline BMI, lixisenatide was beneficial as add-on treatment to basal insulin therapy \pm OADs in Asian individuals with T2D. No significant differences were observed between the BMI subgroups in the changes from baseline in HbA1c, FPG, 2-hour PPG, 2-hour PPG excursion, body weight, BMI, and basal insulin dose at week 24. The proportion of participants with hypoglycemia was low and similar between the BMI subgroups. As expected, lixisenatide significantly reduced HbAlc, 2-hour PPG and PPG excursion levels from baseline at week 24 compared with placebo in all BMI subgroups. Furthermore, in all BMI subgroups, significantly more participants receiving lixisenatide than participants receiving placebo achieved an $\mathrm{HbA1c}<7 \%$. Finally, participants receiving lixisenatide experienced more gastrointestinal adverse events than those receiving placebo, with little difference seen between the BMI subgroups.

In the original publications of GetGoal-Duo 1, GetGoal-L and GetGoal-L-C, lixisenatide as add-on therapy to insulin \pm OADs was associated with significantly greater reductions in HbAlc and PPG compared with placebo in individuals with T2D. ${ }^{29} 3032$ Eto et al 
Table 3 Hypoglycemia and gastrointestinal adverse events by baseline body mass index (BMI) subgroup

\begin{tabular}{|c|c|c|c|c|c|c|c|c|c|}
\hline & \multicolumn{3}{|c|}{$\mathrm{BMI}<25 \mathrm{~kg} / \mathrm{m}^{2}$} & \multicolumn{3}{|c|}{ BMI $25-<30 \mathrm{~kg} / \mathrm{m}^{2}$} & \multicolumn{3}{|c|}{$\mathrm{BMI} \geq 30 \mathrm{~kg} / \mathrm{m}^{2}$} \\
\hline & $\begin{array}{l}\text { PBO } \\
(n=79)\end{array}$ & $\begin{array}{l}\text { LIXI } \\
(n=104)\end{array}$ & $\begin{array}{l}\text { Total } \\
(\mathrm{n}=183)\end{array}$ & $\begin{array}{l}\text { PBO } \\
(n=142)\end{array}$ & $\begin{array}{l}\text { LIXI } \\
(n=134)\end{array}$ & $\begin{array}{l}\text { Total } \\
(\mathrm{n}=276)\end{array}$ & $\begin{array}{l}\text { PBO } \\
(n=42)\end{array}$ & $\begin{array}{l}\text { LIXI } \\
(n=54)\end{array}$ & $\begin{array}{l}\text { Total } \\
(n=96)\end{array}$ \\
\hline $\begin{array}{l}\text { Severe hypoglycemia } \\
\mathrm{n}(\%)\end{array}$ & 0 & 0 & 0 & 0 & 0 & 0 & 0 & 0 & 0 \\
\hline $\begin{array}{l}\text { No of events (events/ } \\
\text { patient-year) }\end{array}$ & 0 & 0 & 0 & 0 & 0 & 0 & 0 & 0 & 0 \\
\hline $\begin{array}{l}\text { Any symptomatic } \\
\text { hypoglycemia } \mathrm{n}(\%)\end{array}$ & $8(10.1)$ & $17(16.4)$ & $25(13.7)$ & $23(16.2)$ & 19 (14.2) & $42(15.2)$ & $2(4.8)$ & $14(25.9)$ & $16(16.7)$ \\
\hline $\begin{array}{l}\text { No of events (events/ } \\
\text { patient-year) }\end{array}$ & $9(0.20)$ & $28(0.42)$ & $37(0.33)$ & $45(0.57)$ & $44(0.54)$ & $89(0.55)$ & $4(0.15)$ & $30(0.75)$ & $34(0.51)$ \\
\hline $\begin{array}{l}\text { Symptomatic } \\
\text { hypoglycemia with BG } \\
<3.3 \mathrm{mmol} / \mathrm{L} \mathrm{n}(\%)\end{array}$ & $6(7.6)$ & $12(11.5)$ & $18(9.8)$ & $16(11.3)$ & $14(10.5)$ & $30(10.9)$ & $2(4.8)$ & $8(14.8)$ & $10(10.4)$ \\
\hline $\begin{array}{l}\text { No of events (events/ } \\
\text { patient-year) }\end{array}$ & $7(0.15)$ & $23(0.34)$ & $30(0.27)$ & $30(0.38)$ & $37(0.46)$ & $67(0.42)$ & $3(0.12)$ & $15(0.37)$ & $18(0.27)$ \\
\hline $\begin{array}{l}\text { Gastrointestinal } \\
\text { adverse events, n (\%) }\end{array}$ & $13(16.5)$ & $42(40.4)$ & $55(30.1)$ & $18(12.7)$ & $52(38.8)$ & $70(25.4)$ & $5(11.9)$ & $20(37.0)$ & $25(26.0)$ \\
\hline Nausea & $4(5.1)$ & 30 (28.9) & 34 (18.6) & $7(4.9)$ & $36(26.9)$ & $43(15.6)$ & $4(9.5)$ & $14(25.9)$ & $18(18.8)$ \\
\hline Vomiting & $2(2.5)$ & $12(11.5)$ & $14(7.7)$ & $1(0.7)$ & $11(8.2)$ & $12(4.4)$ & 0 & 7 (13.0) & $7(7.3)$ \\
\hline Diarrhea & $3(3.8)$ & $4(3.9)$ & $7(3.8)$ & $4(2.8)$ & $6(4.5)$ & $10(3.6)$ & 0 & $1(1.9)$ & $1(1.0)$ \\
\hline
\end{tabular}

BG, blood glucose; LIXI, lixisenatide; PBO, placebo.

found that the mean reductions in HbAlc were smaller, but not significantly so, for participants enrolled in these studies with a lower BMI relative to those with a higher BMI (mean changes between $-0.63 \%$ and $-0.73 \%$; $p=0.88$ between BMI groups). ${ }^{33}$ In contrast, they also found that the mean reductions in PPG with lixisenatide were greater in participants with a lower BMI than those with a higher BMI $(\mathrm{p}<0.0001$ between BMI groups $) .{ }^{33}$ The results of this analysis showed that, in the Asian participants of these studies, there were no significant differences in the changes from baseline observed in HbAlc and 2-hour PPG between BMI subgroups, suggesting that the difference observed between BMI subgroups in PPG in the analysis by Eto et al might be driven by the
non-Asian participants of the studies. The results of this analysis are also in line with another pooled analysis of eight studies in the GetGoal study program, which indicated that baseline BMI had little effect on the change in HbAlc observed with lixisenatide. ${ }^{35}$

In the overall pooled population and the lower BMI subgroups, lixisenatide had little to no effect on FPG compared with placebo. This was an expected result, as participants enrolled in the GetGoal Studies had controlled FPG levels prior to initiating the add-on treatment and shorter acting GLP-1 receptor agonists are known to primarily reduce PPG and not FPG. ${ }^{29} 303236$ However, studies have shown that in individuals receiving basal insulin who are not achieving HbAlc targets,

Table 4 Summary of multivariable regression results of the association of body mass index (BMI) subgroup with different clinical responses in Asian participants with type 2 diabetes

\begin{tabular}{|c|c|c|c|c|}
\hline & \multicolumn{2}{|l|}{ BMI $<25$ vs $\geq 30 \mathrm{~kg} / \mathrm{m}^{2}$} & \multicolumn{2}{|l|}{ BMI $25-<30$ vs $\geq 30 \mathrm{~kg} / \mathrm{m}^{2}$} \\
\hline & $\begin{array}{l}\text { Estimated difference } \\
(95 \% \mathrm{Cl})\end{array}$ & $P$ value & $\begin{array}{l}\text { Estimated difference } \\
(95 \% \mathrm{Cl})\end{array}$ & $P$ value \\
\hline Change in $\mathrm{HbA} 1 \mathrm{c}, \%$ & $0.18(-0.09$ to 0.44$)$ & 0.187 & $-0.02(-0.27$ to 0.22$)$ & 0.857 \\
\hline Change in FPG, mmol/L & $-0.26(-0.83$ to 0.30$)$ & 0.360 & $-0.23(-0.76$ to 0.31$)$ & 0.402 \\
\hline Change in 2-hour PPG, mmol/L & $0.47(-0.74$ to 1.67$)$ & 0.448 & $0.10(-1.04$ to 1.24$)$ & 0.861 \\
\hline Change in body weight, $\mathrm{kg}$ & $0.68(0.09$ to 1.26$)$ & 0.023 & $0.13(-0.42$ to 0.67$)$ & 0.654 \\
\hline Change in basal insulin dose, U/day & $0.48(-1.20$ to 2.15$)$ & 0.576 & $0.14(-1.43$ to 1.71$)$ & 0.858 \\
\hline Endpoint basal insulin dose, U/day & $-13.95(-16.14$ to 11.76$)$ & $<0.001$ & $-9.41(-11.46$ to 7.35$)$ & $<0.001$ \\
\hline Change in basal insulin dose, U/kg/day & $0.007(-0.018$ to 0.032$)$ & 0.593 & $0.005(-0.018$ to 0.029$)$ & 0.645 \\
\hline \multirow[t]{2}{*}{ Endpoint basal insulin dose, U/kg/day } & $0.007(-0.018$ to 0.032$)$ & 0.593 & $0.005(-0.018$ to 0.029$)$ & 0.645 \\
\hline & OR $(95 \% \mathrm{Cl})$ & $P$ value & OR $(95 \% \mathrm{Cl})$ & $P$ value \\
\hline Endpoint $\mathrm{HbA} 1 \mathrm{c}<7 \%$ & 0.97 (0.48 to 1.93$)$ & 0.691 & $1.15(0.60$ to 2.21$)$ & 0.519 \\
\hline Endpoint $\mathrm{HbA} 1 \mathrm{c}<7 \%$ and no body weight gain & $0.40(0.18$ to 0.90$)$ & 0.005 & $1.02(0.50$ to 2.07$)$ & 0.089 \\
\hline
\end{tabular}

FPG, fasting plasma glucose; HbA1c, glycated hemoglobin; PPG, postprandial glucose. 
targeting PPG over FPG is critical as, while both HbAlc is an indication of blood glucose exposure from a combination of both PPG and FPG, PPG is the main contributor to hyperglycemic exposure in these individuals. ${ }^{37}$ Interestingly, in the current analysis, lixisenatide significantly reduced FPG compared with placebo in those individuals with a BMI $\geq 30 \mathrm{~kg} / \mathrm{m}^{2}$. This was not observed by Eto et alin the pooled analysis of the study populations ${ }^{33}$ suggesting that BMI may influence the effect of lixisenatide on FPG levels in the Asian versus non-Asian participants of the GetGoal Studies. However, it is important to highlight that this result may be due to the small sample sizes and with no $\mathrm{p}$ value for interaction between BMI subgroups found for FPG, further studies are warranted to confirm this result in those individuals with a BMI $\geq 30 \mathrm{~kg} / \mathrm{m}^{2}$.

Like other GLP-1 receptor agonists, lixisenatide promotes body weight loss in individuals with T2D. ${ }^{38} \mathrm{In}$ this analysis, a modest mean reduction in body weight of $0.61 \mathrm{~kg}$ over 24 weeks was observed in individuals receiving lixisenatide, compared with an increase of $0.39 \mathrm{~kg}$ in placebo recipients. Lixisenatide was associated with a significantly greater reduction in body weight versus placebo in individuals with a BMI $<25 \mathrm{~kg} / \mathrm{m}^{2}$ or a BMI of $25-<30 \mathrm{~kg} / \mathrm{m}^{2}$ (both $\mathrm{p}<0.001$ ) but not in individuals with a $\mathrm{BMI} \geq 30 \mathrm{~kg} / \mathrm{m}^{2} \quad(\mathrm{p}=0.100 \mathrm{vs}$ placebo $)$. This result is contradictory to that observed by Eto $e t a l$, where a greater baseline BMI tended to be associated with a greater reduction in body weight with lixisenatide add-on treatment. ${ }^{33}$ There may be a number of reasons for this unexpected result in the current analysis. First, the increase in body weight observed in individuals receiving placebo with a BMI $\geq 30 \mathrm{~kg} / \mathrm{m}^{2}$ was smaller than that observed in individuals in the lower BMI subgroups receiving placebo. Second, the group with a BMI $\geq 30 \mathrm{~kg}$ / $\mathrm{m}^{2}$ comprised only $17 \%$ of the total study cohort, so the analysis may have been underpowered to detect a difference in body weight loss between lixisenatide and placebo in this group. The latter reason is supported by the fact that the reduction in body weight with lixisenatide in participants with a BMI $\geq 30 \mathrm{~kg} / \mathrm{m}^{2}$ was similar to that observed in participants with a BMI of $25-30 \mathrm{~kg} / \mathrm{m}^{2}$.

Because of their beneficial effects on weight loss, clinical studies of GLP-1 receptor agonists are often enriched with individuals whose BMIs are in the overweight or obese categories. Moreover, average weight and height differ between ethnic groups, so the BMI thresholds that define overweight/obesity in a Caucasian population are not necessarily applicable in Asian individuals. ${ }^{39}$ The current study demonstrates that lixisenatide as add-on therapy to basal insulin is effective in an Asian population, irrespective of BMI, and confirms previous data that lixisenatide efficacy is independent of BMI from studies in Caucasian or Japanese individuals with diabetes. ${ }^{40-42}$

The results of this analysis are in line with other analyses conducted in individuals receiving other GLP-1 receptor agonists. Studies of both liraglutide ${ }^{4344}$ and exenatide ${ }^{45-49}$ indicate that baseline BMI values are not predictive of the reduction in HbAlc seen with these treatments. While
Fadini et al reported that baseline BMI was predictive for the reduction in body weight observed with liraglutide treatment ${ }^{43}$ none of the other studies of GLP-1 receptor agonists found a correlation between baseline BMI and body weight loss. ${ }^{4-49}$

There are some limitations to this analysis, the main one being the post hoc nature of this analysis. While the retrospective design and imbalance in participant numbers between subgroups limit the internal validity of these results, the results indicate that BMI does not appear to have an effect on the known effectiveness and safety of lixisenatide in Asian individuals with T2D. Further prospective studies evaluating the effect of lixisenatide and other GLP-1 receptor agonists in participants with different BMIs are warranted to confirm these results. Another limitation of this analysis may be the BMI categories chosen, as studies have suggested that individuals of Asian descent have different health risks associated with BMI compared with those of European descent. However, a WHO expert consultation addressed these issues in the early 2000s, concluding that the WHO BMI cut-off points should be retained as international classifications for all populations, ${ }^{34}$ and as such the standard BMI categories were assessed in this analysis. However, further studies investigating the effects of different BMI/waist circumference or precise adipose tissue measurement on the efficacy and tolerability of lixisenatide are warranted. Finally, given the design of the original GetGoal Studies, we were unable to determine the true effect of lixisenatide +basal insulin treatment on FPG, or if BMI had any influence on the glucose-lowering effect of this combination, as during the run-in period basal insulin treatment was titrated to achieve optimal FPG levels. Again, a study investigating lixisenatide +basal insulin in individuals with elevated FPG levels, as well as the influence of BMI on the treatment effect, is warranted.

\section{CONCLUSION}

The findings of this post hoc analysis indicate that BMI does not impact on the ability of lixisenatide to optimize glycemic control in Asian individuals with T2D unable to achieve their HbAlc glycemic targets on basal insulin \pm OADs. In clinical practice, there is a large diversity in the BMI profiles of Asian individuals receiving basal insulin who require additional treatment, so this favorable effect of lixisenatide on glycemic control, independent of BMI, is promising and supports the combination of basal insulin +lixisenatide in these individuals.

\section{Author affiliations}

${ }^{1}$ Department of Endocrinology, Drum Tower Hospital Affiliated to Nanjing University Medical School, Nanjing, China

${ }^{2}$ Department of Medical Affair, Sanofi, Shanghai, China

Acknowledgements We thank the participants, investigators, and their staff for participating in the study. We would also like to thank Simone Tait of Springer Healthcare Communications who wrote the outline and first draft of this article. This medical writing assistance was funded by Sanofi Aventis. 
Contributors DZ, XZ and HY designed the study. WW was involved in data acquisition. MZ performed the statistical analysis. WF, RM and GW were involved in drafting the manuscript and DZ, WW, and XZ critically revised the manuscript. All authors read and approved the final manuscript.

Funding The GetGoal Studies and this post hoc analysis were supported by Sanofi. Assistance for the development of this article, as well as the article processing fee, was funded by Sanofi.

Competing interests WF, WW, RM and DZ declare no conflict of interest. GW, MZ, $\mathrm{XZ}$ and HY are employees of Sanofi China.

Patient consent for publication Not required.

Ethics approval The data in this study were derived from previous clinical trials. The Ethics Committees and Institutional Boards of those studies are detailed in the original publications. All procedures performed in those studies were in accordance with the authors' institutions' ethical recommendations and with the 1964 Helsinki Declaration and its later amendments.

Provenance and peer review Not commissioned; externally peer reviewed.

Data availability statement Data are available upon reasonable request. Qualified researchers may request access to patient-level data and related study documents including the clinical study report, study protocol with any amendments, blank case report form, statistical analysis plan, and dataset specifications. Patient-level data will be anonymized, and study documents will be redacted to protect the privacy of trial participants. Further details on Sanofi's data sharing criteria, eligible studies, and process for requesting access can be found at: https://www.clinicalstudydat arequest.com.

Supplemental material This content has been supplied by the author(s). It has not been vetted by BMJ Publishing Group Limited (BMJ) and may not have been peer-reviewed. Any opinions or recommendations discussed are solely those of the author(s) and are not endorsed by BMJ. BMJ disclaims all liability and responsibility arising from any reliance placed on the content. Where the content includes any translated material, BMJ does not warrant the accuracy and reliability of the translations (including but not limited to local regulations, clinical guidelines, terminology, drug names and drug dosages), and is not responsible for any error and/or omissions arising from translation and adaptation or otherwise.

Open access This is an open access article distributed in accordance with the Creative Commons Attribution Non Commercial (CC BY-NC 4.0) license, which permits others to distribute, remix, adapt, build upon this work non-commercially, and license their derivative works on different terms, provided the original work is properly cited, appropriate credit is given, any changes made indicated, and the use is non-commercial. See: http://creativecommons.org/licenses/by-nc/4.0/.

ORCID iD

Dalong Zhu http://orcid.org/0000-0002-1064-1261

\section{REFERENCES}

1 Buse JB, Wexler DJ, Tsapas A, et al. 2019 update to: management of hyperglycemia in type 2 diabetes, 2018. A consensus report by the American diabetes association (ADA) and the European association for the study of diabetes (EASD). Diabetes Care 2020;43:487-93.

2 Kahn SE, Cooper ME, Del Prato S. Pathophysiology and treatment of type 2 diabetes: perspectives on the past, present, and future. Lancet 2014;383:1068-83.

3 NCD Risk Factor Collaboration (NCD-RisC). Worldwide trends in diabetes since 1980: a pooled analysis of 751 population-based studies with 4.4 million participants. Lancet 2016;387:1513-30.

4 Ma S, Xi B, Yang L, et al. Trends in the prevalence of overweight, obesity, and abdominal obesity among Chinese adults between 1993 and 2015. Int J Obes 2021;45:427-37.

5 Bays HE, Chapman $\mathrm{RH}$, Grandy S, et al. The relationship of body mass index to diabetes mellitus, hypertension and dyslipidaemia: comparison of data from two national surveys. Int J Clin Pract 2007;61:737-47.

6 Boffetta P, McLerran D, Chen Y, et al. Body mass index and diabetes in Asia: a cross-sectional pooled analysis of 900,000 individuals in the Asia cohort Consortium. PLoS One 2011;6:e19930.

7 NCD Risk Factor Collaboration (NCD-RisC). Trends in adult bodymass index in 200 countries from 1975 to 2014: a pooled analysis of 1698 population-based measurement studies with $19 \cdot 2$ million participants. Lancet 2016;387:1377-96.
$8 \mathrm{He} \mathrm{Y,} \mathrm{Li} \mathrm{Y,} \mathrm{Yang} \mathrm{X,} \mathrm{et} \mathrm{al.} \mathrm{The} \mathrm{dietary} \mathrm{transition} \mathrm{and} \mathrm{its} \mathrm{association}$ with cardiometabolic mortality among Chinese adults, 1982-2012: a cross-sectional population-based study. Lancet Diabetes Endocrinol 2019;7:540-8.

9 Wilding JPH. The importance of weight management in type 2 diabetes mellitus. Int J Clin Pract 2014;68:682-91.

10 Rhee EJ. Diabetes in Asians. Endocrinol Metab 2015;30:263-9.

11 Kodama K, Tojjar D, Yamada S, et al. Ethnic differences in the relationship between insulin sensitivity and insulin response: a systematic review and meta-analysis. Diabetes Care 2013;36:1789-96.

12 Torréns JI, Skurnick J, Davidow AL, et al. Ethnic differences in insulin sensitivity and beta-cell function in premenopausal or early perimenopausal women without diabetes: the study of women's health across the nation (Swan). Diabetes Care 2004;27:354-61.

13 Møller JB, Pedersen M, Tanaka H, et al. Body composition is the main determinant for the difference in type 2 diabetes pathophysiology between Japanese and Caucasians. Diabetes Care 2014;37:796-804.

14 Wang T, Lu J, Shi L, et al. Association of insulin resistance and $\beta$-cell dysfunction with incident diabetes among adults in China: a nationwide, population-based, prospective cohort study. Lancet Diabetes Endocrinol 2020;8:115-24.

15 Huxley R, James WPT, Barzi F, et al. Ethnic comparisons of the cross-sectional relationships between measures of body size with diabetes and hypertension. Obes Rev 2008;9 Suppl 1:53-61.

16 Chan JCN, Malik V, Jia W, et al. Diabetes in Asia: epidemiology, risk factors, and pathophysiology. JAMA 2009;301:2129-40.

17 Ramachandran A, Snehalatha C, Shetty AS, et al. Trends in prevalence of diabetes in Asian countries. World J Diabetes 2012:3:110-7.

18 Ma RCW, Chan JCN. Type 2 diabetes in East Asians: similarities and differences with populations in Europe and the United States. Ann N Y Acad Sci 2013;1281:64-91.

19 Hemmingsson $\mathrm{E}$. The unparalleled rise of obesity in China: a call to action. Int J Obes 2021;45:921-2.

20 Unger RH, Clark GO, Scherer PE, et al. Lipid homeostasis, lipotoxicity and the metabolic syndrome. Biochim Biophys Acta 2010;1801:209-14

21 Mocarski M, Yeaw J, Divino V, et al. Slow titration and delayed intensification of basal insulin among patients with type 2 diabetes. $J$ Manag Care Spec Pharm 2018;24:390-400.

22 Wu N, Aagren M, Boulanger L, et al. Assessing achievement and maintenance of glycemic control by patients initiating basal insulin. Curr Med Res Opin 2012;28:1647-56.

23 American Diabetes Association. 9. Pharmacologic Approaches to Glycemic Treatment: Standards of Medical Care in Diabetes-2020. Diabetes Care 2020;43:S98-110.

24 Moghissi ES. Treating patients with diabetes of long duration: GLP-1 receptor agonists and insulin in combination. J Am Osteopath Assoc 2014;114:22-9.

25 Aroda VR. A review of GLP-1 receptor agonists: evolution and advancement, through the lens of randomised controlled trials. Diabetes Obes Metab 2018;20 Suppl 1:22-33.

26 Scott LJ. Lixisenatide: a review of its use in patients with type 2 diabetes mellitus. BioDrugs 2013;27:509-23.

27 Levin P, Fan T, Song X, et al. Comparing clinical outcomes and costs for different treatment intensification approaches in patients with type 2 diabetes uncontrolled on basal insulin: adding glucagon-like peptide 1 receptor agonists versus adding rapid-acting insulin or increasing basal insulin dose. Endocr Pract 2017;23:1316-24.

28 Yoon J-H, Min SH, Ahn CH, et al. Comparison of non-insulin antidiabetic agents as an add-on drug to insulin therapy in type 2 diabetes: a network meta-analysis. Sci Rep 2018;8:4095.

29 Riddle MC, Aronson R, Home P, et al. Adding once-daily lixisenatide for type 2 diabetes inadequately controlled by established basal insulin: a 24-week, randomized, placebo-controlled comparison (GetGoal-L). Diabetes Care 2013;36:2489-96.

30 Riddle MC, Forst T, Aronson R, et al. Adding once-daily lixisenatide for type 2 diabetes inadequately controlled with newly initiated and continuously titrated basal insulin glargine: a 24-week, randomized placebo-controlled study (GetGoal-Duo 1). Diabetes Care 2013;36:2497-503.

31 Seino Y, Min KW, Niemoeller E, et al. Randomized, double-blind, placebo-controlled trial of the once-daily GLP-1 receptor agonist lixisenatide in Asian patients with type 2 diabetes insufficiently controlled on basal insulin with or without a sulfonylurea (GetGoal-LAsia). Diabetes Obes Metab 2012;14:910-7.

32 Yang W, Min K, Zhou Z, et al. Efficacy and safety of lixisenatide in a predominantly Asian population with type 2 diabetes insufficiently 
controlled with basal insulin: the GetGoal-L-C randomized trial. Diabetes Obes Metab 2018;20:335-43.

33 Eto K, Naito Y, Seino Y. Evaluation of the efficacy and safety of lixisenatide add-on treatment to basal insulin therapy among T2DM patients with different body mass indices from GetGoal trials. Diabetol Metab Syndr 2015;7:106.

34 WHO Expert Consultation. Appropriate body-mass index for Asian populations and its implications for policy and intervention strategies. Lancet 2004;363:157-63.

35 Blonde L, Chava P, Dex T, et al. Predictors of outcomes in patients with type 2 diabetes in the lixisenatide GetGoal clinical trials. Diabetes Obes Metab 2017;19:275-83.

36 Nuffer W, Guesnier A, Trujillo JM. A review of the new GLP-1 receptor agonist/basal insulin fixed-ratio combination products. Ther Adv Endocrinol Metab 2018:9:69-79.

37 Riddle M, Umpierrez G, DiGenio A, et al. Contributions of basal and postprandial hyperglycemia over a wide range of $\mathrm{A} 1 \mathrm{C}$ levels before and after treatment intensification in type 2 diabetes. Diabetes Care 2011;34:2508-14

38 Drab SR. Glucagon-Like peptide-1 receptor agonists for type 2 diabetes: a clinical update of safety and efficacy. Curr Diabetes Rev 2016;12:403-13.

39 Hood K, Ashcraft J, Watts K, et al. Allometric scaling of weight to height and resulting body mass index thresholds in two Asian populations. Nutr Diabetes 2019;9:2.

40 Davies MJ, Leiter LA, Guerci B, et al. Impact of baseline glycated haemoglobin, diabetes duration and body mass index on clinical outcomes in the LixiLan-O trial testing a titratable fixed-ratio combination of insulin glargine/lixisenatide (iGlarLixi) vs insulin glargine and lixisenatide monocomponents. Diabetes Obes Metab 2017;19:1798-804.
41 Seino H, Onishi Y, Naito Y, et al. Lixisenatide improves glycemic outcomes of Japanese patients with type 2 diabetes: a metaanalysis. Diabetol Metab Syndr 2016;8:36.

42 Terauchi Y, Yabe D, Kaneto $\mathrm{H}$, et al. Benefits of the fixed-ratio combination of insulin glargine 100 units $/ \mathrm{mL}$ and lixisenatide (iGlarLixi) in Japanese people with type 2 diabetes: A subgroup and time-to-control analysis of the LixiLan JP phase 3 trials. Diabetes Obes Metab 2020;22 Suppl 4:35-47.

43 Fadini GP, Simioni N, Frison V, et al. Independent glucose and weight-reducing effects of liraglutide in a real-world population of type 2 diabetic outpatients. Acta Diabetol 2013;50:943-9.

44 Lapolla A, Frison V, Bettio M, et al. Correlation between baseline characteristics and clinical outcomes in a large population of diabetes patients treated with liraglutide in a real-world setting in Italy. Clin Ther 2015;37:574-84.

45 Khan M, Ouyang J, Perkins K, et al. Determining predictors of early response to exenatide in patients with type 2 diabetes mellitus. $J$ Diabetes Res 2015;2015:1-9.

46 Song SO, Kim KJ, Lee B-W, et al. Tolerability, effectiveness and predictive parameters for the therapeutic usefulness of exenatide in obese, Korean patients with type 2 diabetes. J Diabetes Investig 2014;5:554-62.

47 Anderson SL, Trujillo JM, McDermott M, et al. Determining predictors of response to exenatide in type 2 diabetes. J Am Pharm Assoc 2012;52:466-71.

48 Gorgojo-Martínez JJ, Gargallo-Fernández MA, Brito-Sanfiel M, et al. Real-World clinical outcomes and predictors of glycaemic and weight response to exenatide once Weekly in patients with type 2 diabetes: the CIBELES project. Int J Clin Pract 2018;72:e13055.

49 Blonde L, Pencek R, MacConell L. Association among weight change, glycemic control, and markers of cardiovascular risk with exenatide once Weekly: a pooled analysis of patients with type 2 diabetes. Cardiovasc Diabetol 2015;14:12. 